\title{
Effect of Lactobacillus Fermentation on the Anti-Inflammatory Potential of Turmeric
}

\author{
Cheng Chung Yong ${ }^{1 \dagger}$, Yonghee Yoon ${ }^{2 \dagger}$, Hee Sub Yoo $^{2}$, and Sejong $\mathrm{Oh}^{1 *}$ \\ ${ }^{1}$ Division of Animal Science, Chonnam National University, Gwangju, 61186, Republic of Korea \\ ${ }^{2}$ JNBIO, Jeonnam, 57059, Republic of Korea
}

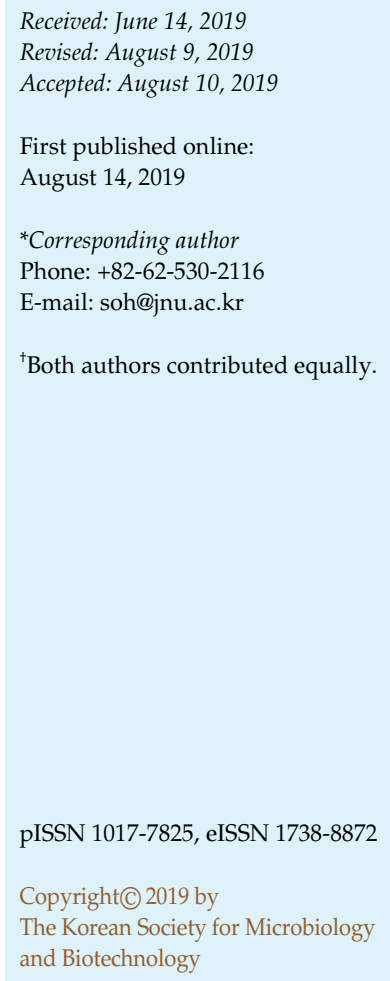

Curcumin, the major bioactive constituent of turmeric, has been reported to have a wide range of pharmacological benefits; however, the low solubility in water has restricted its systemic bioavailability and therapeutic potential. Therefore, in the current study, we aimed to investigate the effect of turmeric fermentation on its curcumin content and anti-inflammatory activity by using several lactic acid bacteria. Fermentation with Lactobacillus fermentum significantly increased the curcumin content by $9.76 \%$ while showing no cytotoxicity in RAW 246.7 cells, as compared to the unfermented turmeric, regardless of the concentration of L. fermentum-fermented turmeric. The L. fermentum-fermented turmeric also promoted cell survival; a significantly higher number of viable cells in lipopolysaccharide (LPS)-induced RAW 264.7 cells were observed as compared to those treated with unfermented turmeric. It also displayed promising DPPH scavenging $(7.88 \pm 3.36 \%)$ and anti-inflammatory activities by significantly reducing the nitrite level and suppressing the expression of the pro-apoptotic tumor necrosis factor-alpha and Toll-like receptor-4 in LPS-induced RAW 264.7 cells. Western blot analysis further revealed that the anti-inflammatory activity of the fermented turmeric was exerted through suppression of the c-Jun N-terminal kinase signal pathway, but not in unfermented turmeric. Taken together, the results suggested that fermentation with lactic acid bacteria increases the curcumin content of turmeric without increasing its cytotoxicity, while strengthening the specific pharmacological activity, thus, highlighting its potential application as a functional food ingredient.

Keywords: Turmeric, curcumin, Lactobacillus, RAW 264.7 macrophage cells, anti-inflammatory

\section{Introduction}

Curcuma longa, commonly known as turmeric, is a member of the Zingiberaceae family, widely cultivated in India, China, and other Southeast Asian countries [1]. In addition to its use as a spice, food additive and natural yellow food coloring, turmeric also has a long history of use in traditional Ayurvedic medicine for various diseases and acts as a "blood purifier" [2]. In addition to alleviating inflammatory conditions, numerous studies have reported the pharmacological properties and benefits of turmeric consumption, including anti-Alzheimer's activity [3, 4], hypolipidemic effect [5,6], and anti-mutagenic activity [7], attributed to the active ingredient curcumin.
Curcumin (diferuloylmethane), the major bioactive constituent of turmeric with a vibrant yellow appearance, was first identified in 1910 [8]. Many researchers have demonstrated the ability of curcumin to interact with numerous molecular targets in inflammation, including impairing the pro-inflammatory cytokines, tumor necrosis factor-alpha (TNF- $\alpha$ ) and interleukin-1 (IL-1) production in Escherichia coli lipopolysaccharide (LPS)-induced human monocytic macrophages and L929 fibroblast. It also inhibited the activation of nuclear factor-kappa B (NF-kB), a regulator of numerous inflammation-related genes, and the production of nitric oxide [9, 10]. However, as a lipophilic polyphenol, curcumin is nearly insoluble in water, limiting its systemic bioavailability to the host. 
Upon consumption, curcumin is rapidly metabolized, conjugated in the liver, and excreted from the body [11].

Recently, plant-based fermentation by probiotic strains has drawn the attention of both scientific researchers and agricultural industries as a way to improve the nutritional value, flavor, and aroma of food, and for application as a feed additive or adjuvant to enhance the performance of livestock [12]. Probiotics are well known for their beneficial effects on the host; hence, fermentation of plant resources with probiotics might synergistically amplify their beneficial properties. To date, several fermented turmeric products have been developed that not only enhance liver function but also improve palatability while having antioxidant, anti-obesity, and antimicrobial activities [13-16]. However, there are limited studies reporting the immuno-modulatory activity of Lactobacillus-fermented turmeric upon bacterial infections in the host [17]. Therefore, this study aimed to discover the effect of Lactobacillus fermentation on curcumin content in turmeric and the immuno-modulatory events occurring in LPS-induced macrophages upon treatment with Lactobacillus-fermented turmeric. To our best knowledge, this is the first report demonstrating the anti-inflammatory activity of Lactobacillus-fermented turmeric in LPS-induced macrophages through the JNK signal pathway.

\section{Materials and Methods}

\section{Cell Culture and Chemicals}

Jungnong Bio Inc. (Korea) provided turmeric and Lactobacillusfermented turmeric powders, which were heat-sterilized prior to freeze-drying into the final product, turmeric powder. Murine macrophage RAW 264.7 cells were obtained from the Korea Cell Line Bank (Korea) and maintained in Dulbecco's Modified Eagle's Medium (DMEM; Invitrogen, USA) supplemented with 10\% (v/v) fetal bovine serum (FBS) and $1 \%(\mathrm{v} / \mathrm{v})$ antibiotic/antimycotic (Invitrogen) at $37^{\circ} \mathrm{C}$ in $5 \% \mathrm{CO}_{2}$ humidified atmosphere.

\section{High-Performance Liquid Chromatography Analysis of Lactobacillus- Fermented Turmeric}

The curcumin content of the Lactobacillus-fermented and unfermented turmeric was determined by high-performance liquid chromatography (HPLC) analysis according to the method of Tønnesen et al. [18]. The HPLC analysis was performed at the Advanced Analysis Center, Korea Institute of Science and Technology, Seoul, Korea.

\section{In Vitro Cytotoxicity Assay}

The RAW 264.7 cells were seeded in a 96-well plate at a density of $1 \times 10^{5}$ cells/well in DMEM medium and maintained under conditions mentioned previously until $70 \%$ confluency. The cells were treated with various concentrations of Lactobacillus-fermented and unfermented turmeric samples (500.00, 250.00, 125.00, 62.50, and $31.25 \mu \mathrm{g} / \mathrm{ml}$ in $0.1 \%$ [v/v] dimethyl sulfoxide, DMSO) for $24 \mathrm{~h}$ at $37^{\circ} \mathrm{C}$ in $5 \% \mathrm{CO}_{2}$ humidified atmosphere. The cellular cytotoxicity of Lactobacillus-fermented and unfermented turmeric samples was quantified by the MTT assay [19].

\section{Lipopolysaccharide-Induced Cell Viability Assay}

For cell viability assay, RAW 264.7 cells were seeded in a 96well plate at a density of $1 \times 10^{5}$ cells/well in DMEM medium and maintained under conditions mentioned previously until $70 \%$ confluency. The cells were treated with $1 \mu \mathrm{g} / \mathrm{ml}$ of lipopolysaccharide (LPS; Escherichia coli O111:B4; Sigma-Aldrich, USA) and various concentrations of Lactobacillus-fermented and unfermented turmeric samples for $24 \mathrm{~h}$. The viability of LPSinduced RAW 264.7 cells was determined via MTT assay [19].

\section{Nitric Oxide Determination}

The nitric oxide (NO) production in LPS-induced RAW 264.7 cells, upon treatment with Lactobacillus-fermented and unfermented turmeric samples, was determined by measuring the nitrite accumulated in the culture media with Griess reagent $(1.0 \%[\mathrm{w} / \mathrm{v}]$ sulfanilamide in $2.5 \%[\mathrm{v} / \mathrm{v}]$ phosphoric acid and $0.1 \%[\mathrm{w} / \mathrm{v}]$ naphtylethylenediamine-dihydrochloride). Briefly, the culture supernatant was mixed with an equal volume of Griess reagent (ratio 1:1) in a 96-well plate and incubated at room temperature for $15 \mathrm{~min}$. The absorbance was measured at $540 \mathrm{~nm}$, and fresh culture medium was used as blank. A standard curve was constructed using $0-100 \mu \mathrm{M}$ sodium nitrite [19].

\section{2,2-Diphenyl-1-Picrylhydrazyl (DPPH) Radical Scavenging Assay}

The Lactobacillus-fermented and unfermented turmeric samples were dissolved in $95 \%(\mathrm{v} / \mathrm{v})$ ethanol and mixed with $0.1 \mathrm{mM}$ DPPH in 3:1 ratio in a 96-well plate. The mixtures were allowed to react in the dark for $30 \mathrm{~min}$. The absorbance was measured at $517 \mathrm{~nm}$ and ethanol was used as a control. L-ascorbic acid was used as a positive control. The DPPH radical scavenging activity was calculated using the following equation [20]:

$\mathrm{DPPH}$ radical scavenging activity $(\%)=\left[1-\left(\mathrm{OD}_{517 \text { sample }} / \mathrm{OD}_{517 \text { control }}\right)\right] \times 100$

\section{Determination of the Level of Pro-Inflammatory Factors}

RAW 264.7 cells $\left(3 \times 10^{5}\right.$ cells/well in 6-well plate) were cultured with $1 \mu \mathrm{g} / \mathrm{ml}$ of LPS and Lactobacillus-fermented turmeric samples for $24 \mathrm{~h}$. Total cellular RNA was isolated using GeneAll Ribospin (GeneAll Biotechnology Co., Ltd, Korea) and reversetranscripted using Maxime RT Premix Kit (iNtRON Biotechnology, Korea), according to the manufacturer's instructions. A quantitative polymerase chain reaction (qPCR) was performed to determine the gene expression of TNF- $\alpha$ and Toll-like receptor 4 (TLR4) in LPS-induced RAW 264.7 cells using Kapa SYBR qPCR Universal Master Mix (Kapa Biosystems, USA) and a thermal cycler (BioRad, USA). Glyceraldehyde 3-phosphate dehydrogenase (GAPDH) was used as an internal control. The primers used and the annealing 
Table 1. Oligonucleotide primers used in this study.

\begin{tabular}{llcc}
\hline Genes & \multicolumn{1}{c}{ Oligonucleotide sequences } & Annealing temperature & References \\
\hline$T N F-\alpha \mathrm{F}$ & ACTGAACTTCGGGGTGAT & $60^{\circ} \mathrm{C}$ & {$[43]$} \\
$T N F-\alpha \mathrm{R}$ & ACTTGGTGGTTTGCTACG & $60^{\circ} \mathrm{C}$ & {$[43]$} \\
$T L R 4 \mathrm{~F}$ & TTCAGAACTTCAGTGGCTGGATTTA & & \\
$T L R 4 \mathrm{R}$ & GTCTCCACAGCCACCAGATTCTC & $60^{\circ} \mathrm{C}$ & {$[17]$} \\
GAPDH F & CATGACCACAGTCCATGCCATCAC & & \\
GADPH $\mathrm{R}$ & TGAGGTCCACCACCCTGTTGCTGT & & \\
\hline
\end{tabular}

temperature are tabulated in Table 1 . The amplification reaction involved denaturation for $5 \mathrm{~min}$ at $95^{\circ} \mathrm{C}$, followed by 45 cycles of denaturation for $15 \mathrm{sec}$ at $95^{\circ} \mathrm{C}$, annealing for $30 \mathrm{sec}$ at $60^{\circ} \mathrm{C}$, and extension for $30 \mathrm{sec}$ at $72^{\circ} \mathrm{C}$. The expression of each gene was determined via comparative analysis based on $\mathrm{Ct}$ value as follows:

Relative expression $=2^{-\Delta \mathrm{Ct}}$ with $\Delta C t=\mathrm{Ct}_{\text {gene }}-\mathrm{Ct}_{\mathrm{GAPDH}}$

\section{Western Blot Analysis}

RAW 264.7 cells $\left(3 \times 10^{5}\right.$ cells/well in 6-well plate) were cultured with $1 \mu \mathrm{g} / \mathrm{ml}$ of LPS and Lactobacillus-fermented turmeric samples for $24 \mathrm{~h}$. After incubation, the supernatants were discarded, and the total protein was extracted using PRO-PREP Protein Extraction Solution (iNtRON Biotechnology), according to the manufacturer's protocol. The protein concentration was determined using a Pierce BCA Protein Assay Kit (Thermo Fisher Scientific, USA) according to the manufacturer's protocol and the extracted protein was electroblotted onto a nitrocellulose membrane following separation using $12 \%$ SDS-polyacrylamide gel electrophoresis. Membranes were blocked overnight with primary antibodies for $\mathrm{p}-\mathrm{JNK}, \mathrm{TNF}-\alpha$, and $\beta$-actin at $4^{\circ} \mathrm{C}$ in Tween 20-Tris-buffered saline (TTBS), supplemented with $5 \%(\mathrm{w} / \mathrm{v})$ skim milk. Membranes were then washed three times with TTBS, followed by incubation with a horseradish peroxidase-conjugated secondary antibody, and again washed thrice with TTBS prior to development through enhanced chemiluminescence.

\section{Statistical Analyses}

All values were expressed as mean \pm standard deviation from triplicate runs $(n=3)$ and analyzed using SPSS version 20 (IBM SPSS Statistics, USA). Paired T-test analysis was used to determine the difference between two means with a significance level of $\rho<0.05$, while Tukey's multiple range analysis was used to determine the difference between samples with a significance level of $\rho<0.05$.

\section{Results}

\section{Curcumin Content of Unfermented and Lactobacillus-} Fermented Turmeric

HPLC analysis revealed that fermentation with Lactobacillus improved the curcumin content (Table 2). Upon fermentation, the curcumin content was significantly increased by $9.62 \pm 1.17 \%(\rho<0.05)$ in L. fermentum-fermented turmeric and $6.26 \pm 0.95 \%$ in L. plantarum-fermented turmeric, as compared to the unfermented turmeric. Meanwhile, the curcumin content of L. brevis-fermented turmeric was similar to unfermented turmeric, with $1.35 \pm 0.72 \%$ increase only. Overall, the curcumin content in turmeric was markedly enhanced through fermentation with Lactobacillus strains.

\section{Cytotoxicity of Lactobacillus-Fermented Turmeric}

Upon fermentation, the Lactobacillus-fermented turmeric samples did not show cytotoxicity towards RAW 264.7 cells, regardless of the concentration of the fermented turmeric (31.25-500.00 $\mu \mathrm{g} / \mathrm{ml})$, when compared to the control (Fig. 1). Moreover, high concentrations of unfermented turmeric at $500 \mu \mathrm{g} / \mathrm{ml}$ and $250 \mu \mathrm{g} / \mathrm{ml}$ significantly decreased $(\rho<0.05)$ the cell viability of RAW 264.7 cells by $55.86 \pm 3.41 \%$ and $27.18 \pm 8.96 \%$, respectively, compared to the control. The cell viability of RAW264.7 cells was further increased upon treatment with the decreasing concentration of Lactobacillusfermented turmeric samples. This indicates that fermentation

Table 2. HPLC analysis of the curcumin content of Lactobacillus fermented turmeric.

\begin{tabular}{lcc}
\hline Samples & Curcumin content before fermentation, $\mathrm{mg} / \mathrm{g}$ & Curcumin content after fermentation, mg/g \\
\hline L. fermentum-fermented & $1.855 \pm 0.026$ & $2.03 \pm 0.012 * * *$ \\
L. plantarum-fermented & $1.971 \pm 0.010^{* *}$ \\
L. brevis-fermented & $1.880 \pm 0.013$ \\
\hline
\end{tabular}

Results are expressed as mean \pm standard deviation of triplicate runs $(n=3)$. Paired T-test analysis was performed with asterisks $(*)$ indicating that curcumin contents before and after fermentation differ significantly $\left.{ }^{* *} \rho<0.01 ;{ }^{* * *} \rho<0.001\right)$. 


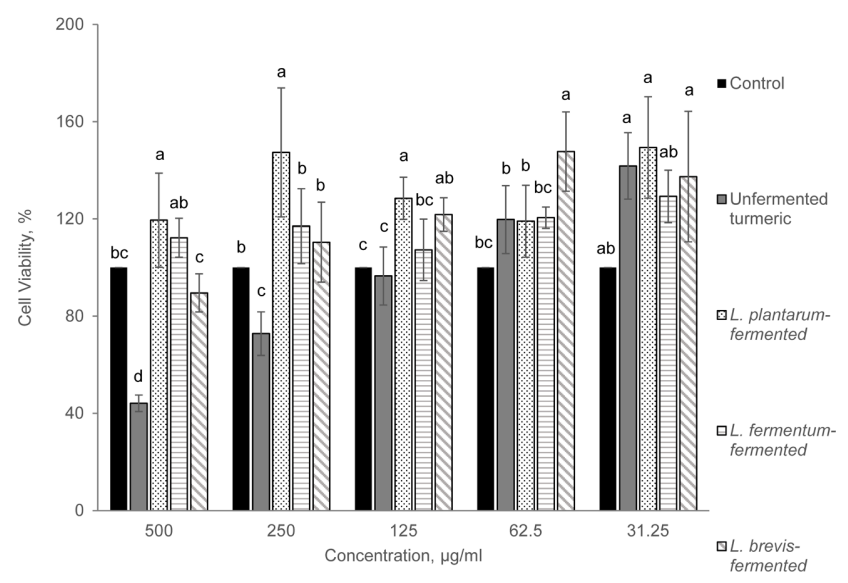

Fig. 1. Cell viability of murine macrophages, RAW 264.7 cells upon treatment with different concentrations of Lactobacillusfermented turmeric (500.00, 250.00, 125.00, 62.50, and $31.25 \mu \mathrm{g} / \mathrm{ml}$ in $0.1 \%$ [v/v] DMSO).

Untreated RAW 264.7 cells were used as naive control. Results are expressed as means \pm standard deviations $(n=3)$. Tukey's multiple range analysis was performed with different lowercase letters $(\mathrm{a}, \mathrm{b}, \mathrm{c}$, and d) demonstrating the significant differences between samples $(\rho<0.05)$.

of turmeric with Lactobacillus reduced the cytotoxicity of turmeric. Considering the toxicity of the unfermented turmeric sample on RAW 264.7 cells at a concentration higher than $250 \mu \mathrm{g} / \mathrm{ml}$, all samples at $500 \mu \mathrm{g} / \mathrm{ml}$ and $250 \mu \mathrm{g} / \mathrm{ml}$ were excluded from subsequent analyses.

\section{Cell Viability of LPS-Induced RAW 264.7 Cells}

In this study, an enhanced protective effect was observed on Lactobacillus-fermented turmeric-treated RAW 264.7 cells upon LPS induction, compared to unfermented turmeric. Upon stimulation with LPS, the cell viability of untreated LPS-induced RAW 264.7 cells was significantly reduced by $18.25 \pm 4.46 \%(\rho<0.05)$, as compared to the naive control (Fig. 2). The unfermented turmeric at $125 \mu \mathrm{g} / \mathrm{ml}$ was unable to protect RAW 264.7 cells from the LPS challenge, and the cell viability was reduced by $25.92 \pm 2.36 \%(\rho<0.05)$. Among Lactobacillus-fermented turmeric samples, only L. fermentum-fermented turmeric at the concentration of $31.25 \mu \mathrm{g} / \mathrm{ml}$ significantly increased the cell viability of LPS-induced RAW 264.7 cells by $11.61 \pm 2.87 \%(\rho<0.05)$ compared to untreated LPS-induced RAW 264.7 cells. Therefore, $31.25 \mu \mathrm{g} / \mathrm{ml} \mathrm{L}$. fermentum-fermented turmeric was selected for subsequent analyses.

\section{Nitric Oxide Assay}

In the current study, the accumulated nitrite in the

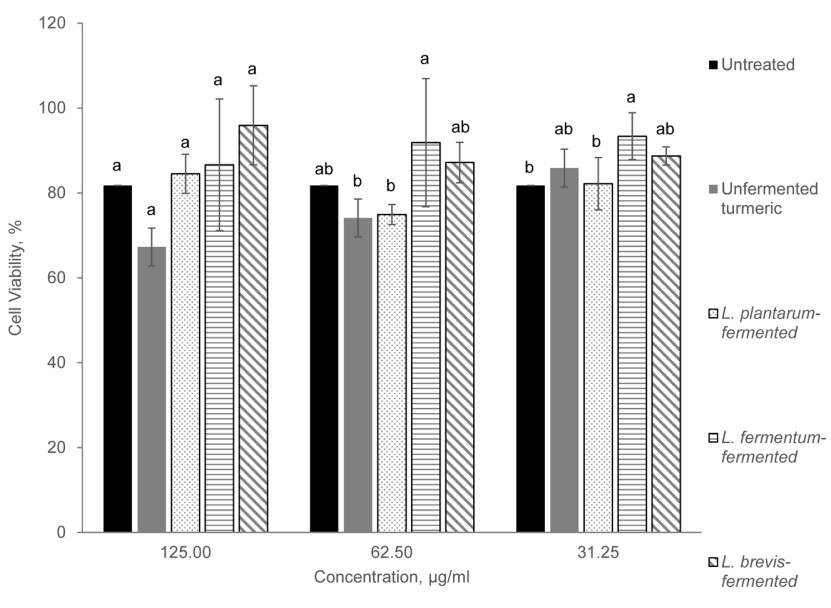

Fig. 2. Cell viability of murine macrophages, RAW 264.7 cells upon stimulation with lipopolysaccharides (LPS) from Escherichia coli and treatment with different concentrations of Lactobacillus-fermented turmeric.

Non-LPS-induced RAW 264.7 cells were used as a naive control. Results are expressed as means \pm standard deviations $(n=3)$. Tukey's multiple range analysis was performed with different lowercase letters ( $\mathrm{a}$ and $\mathrm{b}$ ) demonstrating the significant differences between samples $(\rho<0.05)$.

culture supernatant was determined via the Griess method as an index for NO produced by the LPS-induced RAW 264.7 cells. As shown in Fig. 3, the production of nitrite was reduced upon treatment with $L$. fermentum-fermented turmeric samples. The naive control RAW 264.7 cells (control) generate only a small amount $(16.326 \pm 0.424 \mu \mathrm{M})$ of nitrite. Upon stimulation with LPS, the concentration of nitrite sharply increased to $36.843 \pm 0.448 \mu \mathrm{M}$ in untreated LPS-induced RAW 264.7 cells. Both L. fermentum-fermented turmeric and unfermented turmeric at the concentration of $31.25 \mu \mathrm{g} / \mathrm{ml}$ significantly reduced $(\rho<0.05)$ the production of nitrite by $5.257 \pm 0.462 \mu \mathrm{M}$ and $7.859 \pm 0.417 \mu \mathrm{M}$, respectively, with a slightly higher nitrite reduction effect observed in unfermented turmeric $(28.984 \pm 0.282 \mu \mathrm{M})$ as compared to L. fermentum-fermented turmeric (31.585 \pm $0.163 \mu \mathrm{M})$.

\section{2,2-Diphenyl-1-Picrylhydrazyl (DPPH) Radical Scavenging Activity}

In this study, the antioxidant activity of L. fermentumfermented turmeric was determined by reducing the DPPH radicals. Fig. 4 illustrates a significant DPPH radical scavenging effect $(\rho<0.05)$ of both $L$. fermentum-fermented turmeric $(7.88 \pm 3.36 \%)$ and unfermented turmeric $(9.36 \pm$ $4.24 \%$ ) at the concentration of $31.25 \mu \mathrm{g} / \mathrm{ml}$. Notably, the current findings indicated that both L. fermentum-fermented 


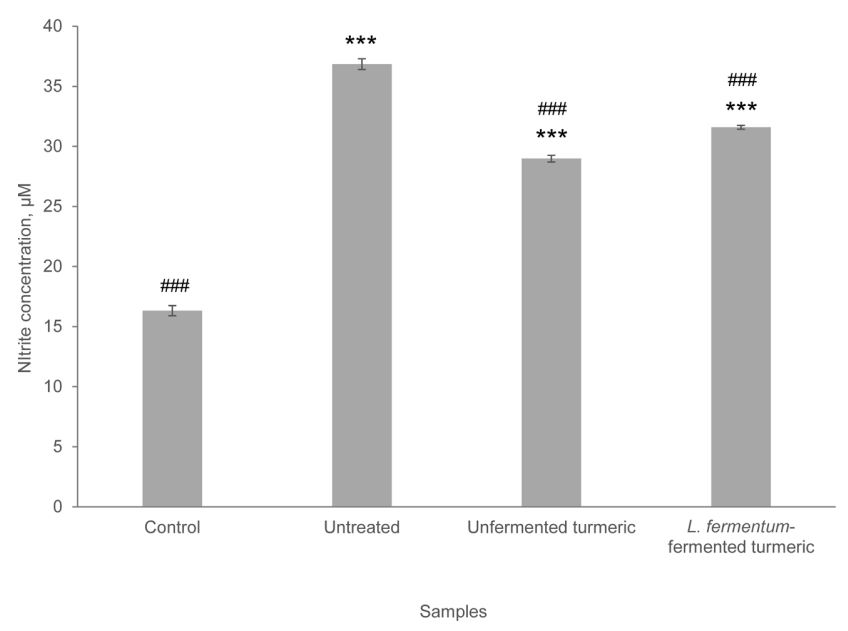

Fig. 3. Effect of L. fermentum-fermented turmeric $(31.25 \mu \mathrm{g} / \mathrm{ml})$ on nitrite production in LPS-induced RAW 264.7 cells.

Results are expressed as means \pm standard deviations $(n=3)$. Paired T-test analysis was performed to determine the group differences. Control group vs. samples $\left({ }^{* * *} \rho<0.001\right)$; untreated group vs. samples $\left({ }^{\# \#} \rho<0.001\right)$.

turmeric and unfermented turmeric show a significantly lower DPPH radical scavenging activity $(\rho<0.05)$ as compared to the positive control.

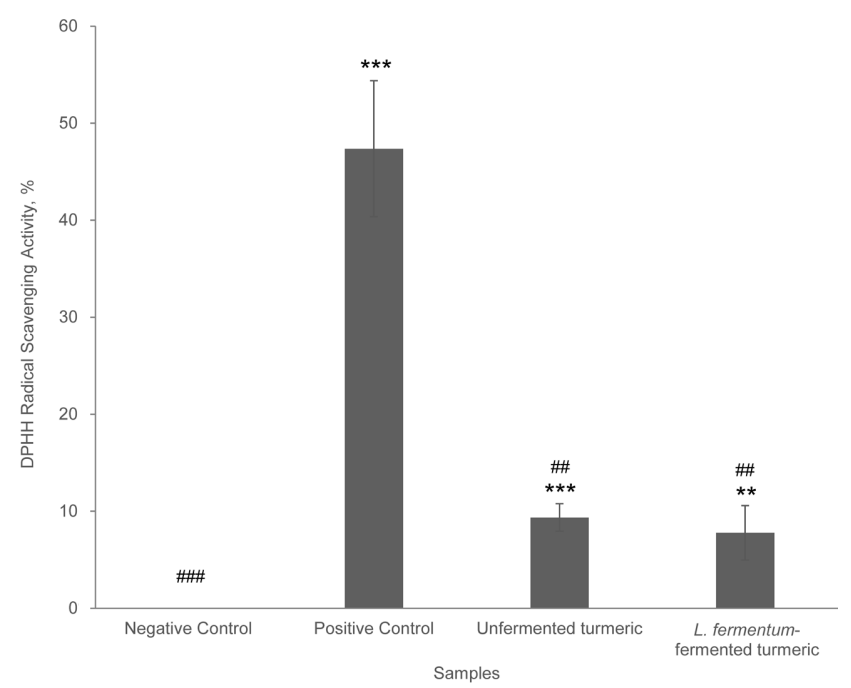

Fig. 4. DPPH radical scavenging activity of L. fermentumfermented $(31.25 \mu \mathrm{g} / \mathrm{ml})$ and unfermented turmeric $(31.25 \mu \mathrm{g} / \mathrm{ml})$. Results are expressed as means \pm standard deviations $(n=3)$. Positive control consists of $500 \mu \mathrm{g} / \mathrm{ml}$ L-ascorbic acid. Paired T-test analysis was performed to determine the group differences. Negative control group vs. samples $\left({ }^{* *} \rho<0.01 ;{ }^{* * *} \rho<0.001\right)$; Positive control group vs.

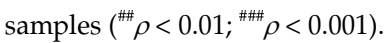

\section{Gene Expression of Pro-Inflammatory Factors}

The gene expressions of TNF- $\alpha$ and TLR4 in LPS-induced RAW 264.7 cells upon treatment with L. fermentumfermented turmeric are shown in Fig. 5. In the present study, both unfermented and L. fermentum-fermented turmeric displayed a profound anti-inflammatory activity by significantly reducing the gene expression level of the pro-inflammatory cytokine, TNF- $\alpha$ in LPS-induced RAW 264.7 cells to the basal level after $24 \mathrm{~h}$. The gene expression level of TNF- $\alpha$ in the untreated control remained at an elevated level $(2.72 \pm 0.46)$ after $24 \mathrm{~h}$. Morever, only L. fermentum-fermented turmeric significantly suppressed $(\rho<0.05)$ the gene expression of the TLR4 to the basal level. The unfermented turmeric was unable to exert a profound effect on suppression of the gene expression of TLR4 upon challenge by LPS induction and remained activated as in the untreated control. Thus, the findings showed that L. fermentum-fermented turmeric exhibited a profound anti-inflammatory activity than unfermented turmeric by suppressing the prolonged production of both TNF- $\alpha$ and TLR4 upon LPS stimulation.

\section{Western Blot Analysis}

The results obtained from the western blot analysis further justified the anti-inflammatory activity of L. fermentum-

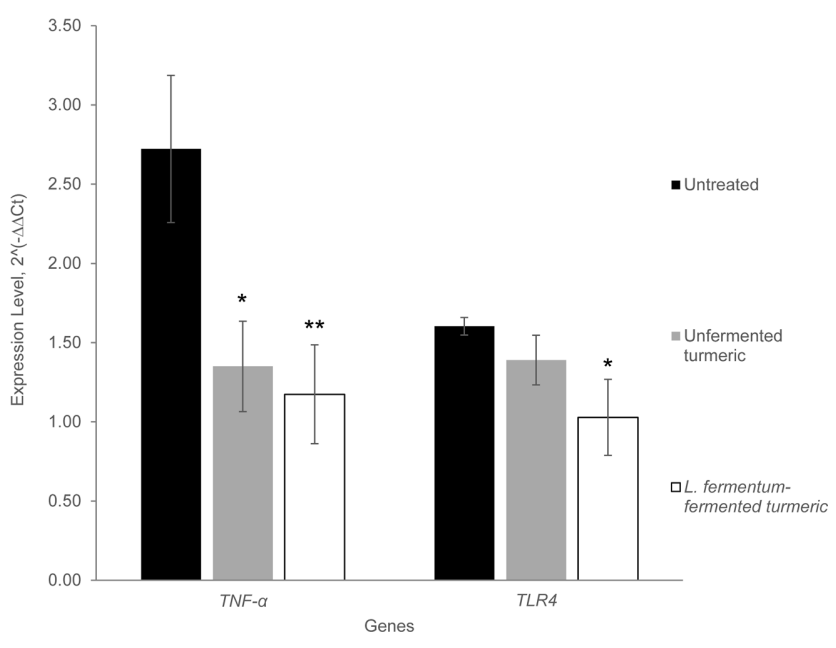

Fig. 5. Effects of L. fermentum-fermented turmeric $(31.25 \mu \mathrm{g} / \mathrm{ml})$ on the gene expression of (a) tumor necrosis factor-alpha (TNF- $\alpha$ ) and (b) Toll-like receptor 4 (TLR4) in LPS-induced RAW 264.7 cells.

Results are expressed as means \pm standard deviations $(n=3)$. Paired T-test analysis was performed, with asterisks $\left({ }^{*}\right)$ indicating that the differences between untreated control and samples within the same group are significant $\left({ }^{*} \rho<0.05 ;{ }^{* *} \rho<0.01\right)$. 
fermented turmeric through the suppression of the phosphorylated-JNK (p-JNK) in RAW 264.7 cells. Treatment with $L$. fermentum-fermented turmeric caused a significant decrease $(\rho<0.05)$ in the level of phosphorylation of JNK in LPS-induced RAW 264.7 cells, while the unfermented turmeric-treated and untreated LPS-induced RAW 264.7 cells demonstrated strong phosphorylation of JNK after 24 $\mathrm{h}$ treatment (Fig. 6). In addition, the western blot analysis further justified the gene expression analysis, where the production of TNF- $\alpha$ was inhibited upon treatment with $L$. fermentum-fermented turmeric, while the level of TNF- $\alpha$ in untreated LPS-induced RAW 264.7 cells remained at an elevated level (Fig. 6).

\section{Discussion}

Turmeric has been long used as a food additive and herbal medicine owing to its wide range of biological activity, including anti-inflammatory $[9,10]$, anti-diabetes [21, 22], and anti-Alzheimer's disease activities [3, 4]. The wide range of pharmacological benefits is attributed to the presence of curcumin, the major bioactive constituent of turmeric. Curcumin only makes up 2-5\% of turmeric [23], hence, probiotics fermentation has been used to improve the curcumin content and pharmacological activities of turmeric. In this study, HPLC analysis revealed that fermentation with Lactobacillus improved the curcumin content. This increment could be attributed to the enzymatic conversion of other curcumin analogs, including bisdemethoxycurcumin or demethoxycurcumin by Lactobacillus in the fermentation process.

Although the curcumin content has been improved via fermentation, it is of utmost importance to validate the cytotoxicity of the Lactobacillus-fermented turmeric. Past studies have shown that the toxicity of unfermented turmeric was directly correlated with its concentration, where a high concentration of unfermented turmeric resulted in a high cellular level of reactive oxygen species (ROS) and cell death [24, 25]. In accordance with the past studies, the results obtained from this study showed that a high concentration of unfermented turmeric reduced the cell viability of RAW 264.7 cells. However, this is the first study that demonstrated that regardless of the concentration used, the Lactobacillus-fermented turmeric samples showed no cytotoxicity towards RAW 264.7 cells. This indicates that fermentation of turmeric with Lactobacillus helps reduce the cytotoxicity of curcumin, which might be attributed to the inhibition of the apoptosis pathway and generation of oxidative stress that leads to cell apoptosis.

Subsequently, efforts were made to determine the protective effect of Lactobacillus-fermented turmeric upon bacterial infections. Previous studies reported that turmeric could enhance phagocytic activity, anti-inflammatory and antioxidant activities of macrophages to prevent cell death
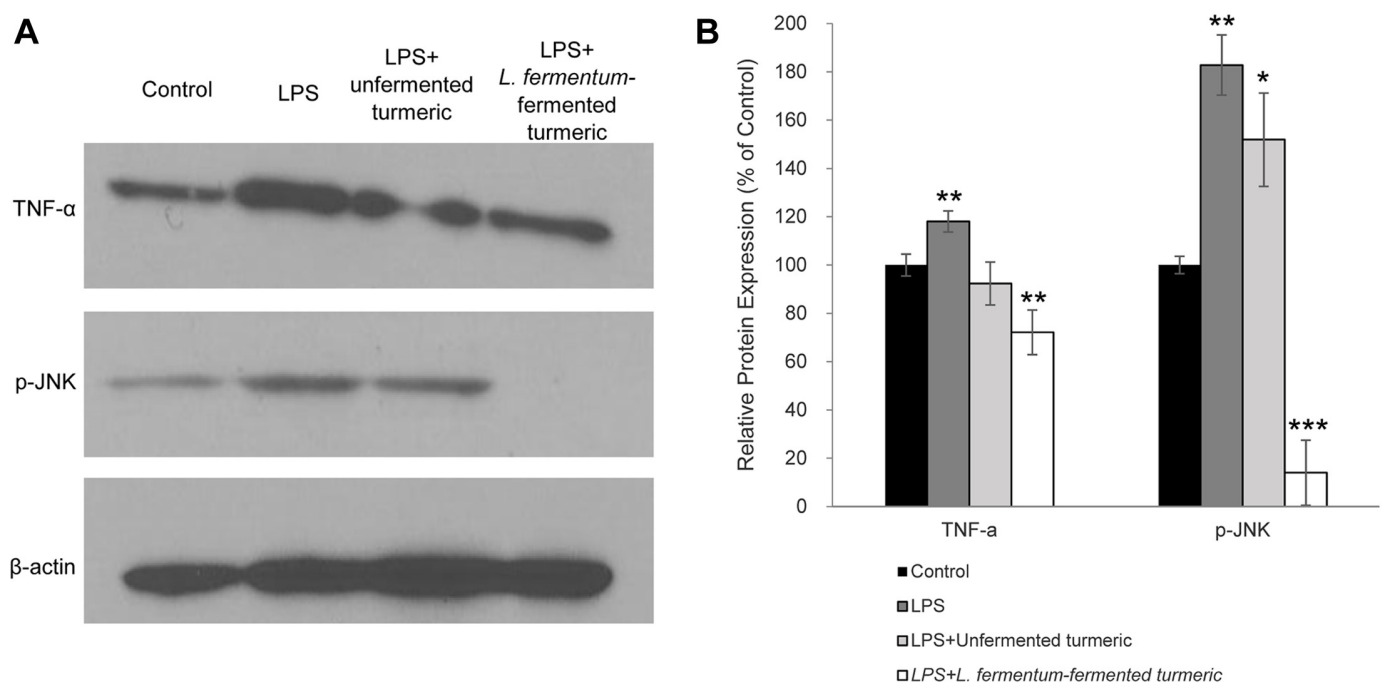

Fig. 6. Effects of L. fermentum-fermented turmeric $(31.25 \mu \mathrm{g} / \mathrm{ml})$ on the activation of phosphorylated-JNK (p-JNK) and TNF- $\alpha$ of LPS-induced RAW 264.7 cells.

(A) Protein levels of p-JNK and TNF- $\alpha$ were detected by western blotting using p-JNK and TNF- $\alpha$ specific antibodies, where $\beta$-actin was used as an internal control. Data shown are representative of three independent experiments $(n=3)$. (B) Relative protein expression of $p-J N K$ and TNF- $\alpha$ was quantified via densitometry analysis. Results are expressed as means \pm standard deviations $(n=3)$. Paired T-test analysis was performed, with asterisks $\left(^{*}\right)$ indicating that the differences between control and samples within the same antibody group are significant $\left({ }^{* *} \rho<0.01 ;{ }^{* * *} \rho<0.001\right)$. 
and apoptosis upon bacterial infection [17, 26]. In the current study, Lactobacillus-fermented turmeric demonstrated an enhanced protective effect on RAW 264.7 cells upon LPS induction when compared to unfermented turmeric. This was likely attributed to the synergistic protective effect of both the curcumin within the turmeric and the Lactobacillus to reduce the generation of oxidative stress and prevent the prolonged production of pro-inflammatory cytokines, resulting in a greater survival rate upon bacterial infection.

Pro-inflammatory cytokines are produced by the activated macrophages and are essential to elicit the inflammatory responses. The TLR4, a transmembrane protein on the surface of macrophages, monocytes, and dendritic cells, belongs to the pattern recognition receptor family and is essential for the initiation of the innate immune response [27]. Hence, the presence of LPS is detected by the immune cells, recognized by TLR4 to form a TLR4-myeloid differentiation protein 2 (MD2)-LPS complex, resulting in the activation of intracellular signaling pathway NF-kB and innate immune system to promote inflammation and drive pro-inflammatory cascades [27-29].

As a pro-inflammatory cytokine, TNF- $\alpha$ initiates the proinflammatory cascades, recruiting and activating various inflammatory cells for recovery purposes [30, 31]. However, the over-production of TNF- $\alpha$ could lead to chronic inflammation and cell apoptosis [31]. In the present study, L. fermentum-fermented turmeric suppressed the production of TNF- $\alpha$ of LPS-induced infection, as evidenced by the results of western blotting. Furthermore, the suppression of TNF- $\alpha$ and TLR4 genes to the basal level (base expression level $=1.0$ ) by L. fermentum-fermented turmeric, was showed in gene expression analysis, as compared to the untreated and unfermented group. Thus, the findings demonstrated that the protective effect of L.fermentumfermented turmeric was attributed to its profound antiinflammatory activity by suppressing the prolonged activation of TLR4 and pro-inflammation cascade, for instance, the over-production of the pro-inflammatory cytokine, TNF- $\alpha$ upon LPS stimulation.

In addition, LPS also induces oxidative stress by stimulating the activated macrophages for the production of NO and ROS. A high level of ROS produced upon LPS stimulation will alter host homeostasis condition, thereby causing oxidative damage and cell apoptosis [32]. Notably, L. fermentum-fermented turmeric also exhibits antioxidant activity by reducing the DPPH radicals. This radical scavenging ability was attributed to the $\mathrm{H}$ atom from the phenolic $\mathrm{OH}$ of curcumin, or the metal-chelating abilities, enzymatic antioxidants, and formation of certain antioxidant biomolecules like exopolysaccharides from Lactobacillus [33-35]. Although fermentation of plant-based products commonly increases the bioactive phenolic compounds and enhances their antioxidant activity, in this study, L. fermentum-fermented turmeric did not augment the antioxidant activity when compared to the unfermented curcumin. A previous study suggested that the changes in antioxidant activity may be influenced by the fermentation conditions as well as the species of the microorganism employed [36].

Previous studies also reported that a high level of NO could induce apoptosis directly or indirectly by rendering many cells susceptible to apoptosis [37, 38]. The data showed that the protective effect of $L$. fermentum-fermented turmeric was also attributed to the reduction of NO. Such reduction was suggested to be associated with the suppression of TNF- $\alpha$ expression. The expression of TNF- $\alpha$ is essential for the synergistic production of NO in LPSinduced macrophages, as demonstrated by Jun et al. [39]. In this study, a lower NO and TNF- $\alpha$ production, and higher cell viability were observed in LPS-induced RAW 264.7 cells upon treatment with L. fermentum-fermented turmeric, suggesting that the NO reduction ability of $L$ fermentumfermented turmeric helps to enhance the survival of LPSinduced RAW 264.7 cells.

Interestingly, the protective effect of L. fermentumfermented turmeric was also shown to be involved with the suppression of the JNK signal transduction pathway. The JNK pathway is induced by activated macrophages in response to LPS and plays a key role in LPS-induced apoptosis [40-42]. The JNK pathway could be either directly activated by LPS, resulting in sustained phosphorylation of JNK or mediated by NO upon LPS-stimulation and ultimately lead to cell death [42]. Notably, treatment with L. fermentum-fermented turmeric caused a decrease in the level of phosphorylation of JNK in LPS-induced RAW 264.7 cells. This could be either attributed to direct inhibition by L. fermentum-fermented turmeric or indirectly through the suppression of NO production, or a combination of both. Thus, the suppression of the JNK signal pathway by L. fermentum-fermented turmeric resulted in a profound protective effect on the LPS-induced RAW 264.7, as demonstrated by a higher survival rate in the cell viability assay.

The present study clearly demonstrated that Lactobacillus fermentation improved the curcumin content and reduced the cytotoxicity of turmeric. Moreover, the protective effect of turmeric was enhanced upon fermentation, where the profound anti-inflammatory and antioxidant activities 
were demonstrated via the suppression on TNF- $\alpha$ and NO production, the JNK signal pathway, and the reduction of DPPH radicals. The current findings implied that Lactobacillus fermentation could overcome the low curcumin content in turmeric while strengthening the specific pharmacological activities of turmeric, highlighting its potential as a functional food ingredient.

\section{Acknowledgments}

This study was supported by the South Jeolla Province (2016 R \& D Support Program operated by Jeonnam Technopark).

\section{Conflict of Interest}

The authors have no financial conflicts of interest to declare.

\section{References}

1. Ammon HP, Wahl MA. 1991. Pharmacology of Curcuma longa. Planta Med. 57: 1-7.

2. Hatcher H, Planalp R, Cho J, Torti F, Torti S. 2008. Curcumin: from ancient medicine to current clinical trials. Cell. Mol. Life Sci. 65: 1631-1652.

3. Ishrat $\mathrm{T}$, Hoda MN, Khan MB, Yousuf S, Ahmad M, Khan $\mathrm{MM}$, et al. 2009. Amelioration of cognitive deficits and neurodegeneration by curcumin in rat model of sporadic dementia of Alzheimer's type (SDAT). Eur. Neuropsychopharmacol. 19: 636-647.

4. Ma Q-L, Yang F, Rosario ER, Ubeda OJ, Beech W, Gant DJ, et al. 2009. $\beta$-amyloid oligomers induce phosphorylation of tau and inactivation of insulin receptor substrate via c-Jun $\mathrm{N}$-terminal kinase signaling: suppression by omega-3 fatty acids and curcumin. J. Neurosci. 29: 9078-9089.

5. Arafa HM. 2005. Curcumin attenuates diet-induced hypercholesterolemia in rats. Med. Sci. Monit. 11: BR228BR234.

6. Jin S, Hong J-H, Jung S-H, Cho K-H. 2011. Turmeric and laurel aqueous extracts exhibit in vitro anti-atherosclerotic activity and in vivo hypolipidemic effects in a zebrafish model. J. Med. Food. 14: 247-256.

7. Polasa K, Raghuram T, Krishna TP, Krishnaswamy K. 1992. Effect of turmeric on urinary mutagens in smokers. Mutagenesis 7: 107-109.

8. Lampe V, Milobedzka J. 1913. Studien über curcumin. Ber. Dtsch. Chem. Ges. 46: 2235-2240.

9. Chan MM-Y. 1995. Inhibition of tumor necrosis factor by curcumin, a phytochemical. Biochem. Pharmacol. 49: 15511556.
10. Chan MM-Y, Huang H-I, Fenton MR, Fong D. 1998. In vivo inhibition of nitric oxide synthase gene expression by curcumin, a cancer preventive natural product with antiinflammatory properties. Biochem. Pharmacol. 55: 1955-1962.

11. Ireson C, Orr S, Jones DJ, Verschoyle R, Lim C-K, Luo J-L, et al. 2001. Characterization of metabolites of the chemopreventive agent curcumin in human and rat hepatocytes and in the rat in vivo, and evaluation of their ability to inhibit phorbol ester-induced prostaglandin E2 production. Cancer Res. 61: 1058-1064.

12. Gupta S, Abu-Ghannam N. 2012. Probiotic fermentation of plant based products: possibilities and opportunities. Crit. Rev. Food Sci. Nutr. 52: 183-199.

13. Ho JN, Park SJ, Choue R, Lee J. 2013. Standardized ethanol extract of Curcuma longa L. fermented by Aspergillus oryzae promotes lipolysis via activation of cAMP-dependent PKA in 3T3-L1 adipocytes. J. Food Biochem. 37: 595-603.

14. Kim JH, Kim O-K, Yoon H-G, Park J, You Y, Kim K, et al. 2016. Anti-obesity effect of extract from fermented Curcuma longa L. through regulation of adipogenesis and lipolysis pathway in high-fat diet-induced obese rats. Food Nutr. Res. 60: 30428

15. Kim SW, Ha KC, Choi EK, Jung SY, Kim MG, Kwon DY, et al. 2013. The effectiveness of fermented turmeric powder in subjects with elevated alanine transaminase levels: a randomised controlled study. BMC Complement. Altern. Med. 13: 58.

16. Pianpumepong P, Anal AK, Doungchawee G, Noomhorm A. 2012. Study on enhanced absorption of phenolic compounds of Lactobacillus-fermented turmeric (Curcuma longa Linn.) beverages in rats. Int. J. Food Sci. Technol. 47: 2380-2387.

17. Kim SB, Kang BH, Kwon HS, Kang JH. 2011. Antiinflammatory and antiallergic activity of fermented turmeric by Lactobacillus johnsonii IDCC 9203. Microbiol. Biotechnol. Lett. 39: 266-273.

18. Tønnesen HH, Karlsen J. 1983. High-performance liquid chromatography of curcumin and related compounds. J. Chromatogr. A. 259: 367-371.

19. Liu CF, Tseng KC, Chiang SS, Lee BH, Hsu WH, Pan TM. 2011. Immunomodulatory and antioxidant potential of Lactobacillus exopolysaccharides. J. Sci. Food Agric. 91: 2284-2291.

20. Ak T, Gülçin İ. 2008. Antioxidant and radical scavenging properties of curcumin. Chem.Biol. Interact. 174: 27-37.

21. Merrell JG, McLaughlin SW, Tie L, Laurencin CT, Chen AF, Nair LS. 2009. Curcumin-loaded poly ( $\varepsilon$-caprolactone) nanofibres: diabetic wound dressing with anti-oxidant and anti-inflammatory properties. Clin. Exp. Pharmacol. Physiol. 36: 1149-1156.

22. Reddy BV, Sundari JS, Balamurugan E, Menon VP. 2009. Prevention of nicotine and streptozotocin treatment induced circulatory oxidative stress by bis-1, 7-(2-hydroxyphenyl)hepta-1, 6-diene-3, 5-dione in diabetic rats. Mol. Cell. Biochem. 331: 127-133. 
23. Aggarwal BB, Sundaram C, Malani N, Ichikawa H. 2007. Curcumin: the Indian solid gold, pp. 1-75. In Aggarwal BB, Surh Y-J, Shishodia S (eds.), The molecular targets and therapeutic uses of curcumin in health and disease, Springer, Massachusetts, USA.

24. Atsumi T, Fujisawa S, Tonosaki K. 2005. Relationship between intracellular ROS production and membrane mobility in curcumin-and tetrahydrocurcumin-treated human gingival fibroblasts and human submandibular gland carcinoma cells. Oral Dis. 11: 236-242.

25. Garden OJ, Wigmore SJ. 2007. Curcumin induces heme oxygenase 1 through generation of reactive oxygen species, p38 activation and phosphatase inhibition. Int. J. Mol. Med. 19: $165-172$.

26. Bisht K, Choi WH, Park SY, Chung MK, Koh WS. 2009. Curcumin enhances non-inflammatory phagocytic activity of RAW264.7 cells. Biochem. Biophys. Res. Commun. 379: 632-636.

27. Fang W, Bi D, Zheng R, Cai N, Xu H, Zhou R, et al. 2017. Identification and activation of TLR4-mediated signalling pathways by alginate-derived guluronate oligosaccharide in RAW264. 7 macrophages. Sci. Rep. 7: 1663.

28. Kanzler H, Barrat FJ, Hessel EM, Coffman RL. 2007. Therapeutic targeting of innate immunity with Toll-like receptor agonists and antagonists. Nat. Med. 13: 552-559.

29. Vaure C, Liu Y. 2014. A comparative review of toll-like receptor 4 expression and functionality in different animal species. Front. Immunol. 5: 316.

30. Akdis $M$, Burgler $S$, Crameri $R$, Eiwegger $T$, Fujita $H$, Gomez E, et al. 2011. Interleukins, from 1 to 37, and interferon- $\gamma$ : receptors, functions, and roles in diseases. J. Allergy Clin. Immunol. 127: 701-721. e770.

31. Brown KL, Cosseau C, Gardy JL, Hancock RE. 2007. Complexities of targeting innate immunity to treat infection. Trends Immunol. 28: 260-266.

32. Halliwell B. 1996. Antioxidants in human health and disease. Annu. Rev. Nutr. 16: 33-50.

33. Kullisaar T, Zilmer M, Mikelsaar M, Vihalemm T, Annuk H, Kairane C, et al. 2002. Two antioxidative lactobacilli strains as promising probiotics. Int. J. Food Microbiol. 72: 215-224.
34. Lee HY, Park JH, Seok SH, Baek MW, Kim DJ, Lee KE, et al. 2006. Human originated bacteria, Lactobacillus rhamnosus PL60, produce conjugated linoleic acid and show antiobesity effects in diet-induced obese mice. BBA-Mol. Cell Biol. L 1761: 736-744.

35. Barclay LRC, Vinqvist MR, Mukai K, Goto H, Hashimoto $Y$, Tokunaga A, et al. 2000. On the antioxidant mechanism of curcumin: classical methods are needed to determine antioxidant mechanism and activity. Org. Lett. 2: 2841-2843.

36. Hur SJ, Lee SY, Kim YC, Choi I, Kim GB. 2014. Effect of fermentation on the antioxidant activity in plant-based foods. Food Chem. 160: 346-356.

37. Albina JE, Cui S, Mateo RB, Reichner JS. 1993. Nitric oxidemediated apoptosis in murine peritoneal macrophages. $J$. Immunol. 150: 5080-5085.

38. Allione A, Bernabei P, Bosticardo M, Ariotti S, Forni G, Novelli F. 1999. Nitric oxide suppresses human T lymphocyte proliferation through IFN- $\gamma$-dependent and IFN- $\gamma$-independent induction of apoptosis. J. Immunol. 163: 4182-4191.

39. Jun CD, Choi BM, Kim HM, Chung HT. 1995. Involvement of protein kinase $\mathrm{C}$ during taxol-induced activation of murine peritoneal macrophages. J. Immunol. 154: 6541-6547.

40. Deng Y, Ren X, Yang L, Lin Y, Wu X. 2003. A JNKdependent pathway is required for TNF $\alpha$-induced apoptosis. Cell 115: 61-70.

41. Yang X, Khosravi-Far R, Chang HY, Baltimore D. 1997. Daxx, a novel Fas-binding protein that activates JNK and apoptosis. Cell 89: 1067-1076.

42. Seminara AR, Ruvolo PP, Murad F. 2007. LPS/IFN- $\gamma-$ induced RAW 264.7 apoptosis is regulated by both nitric oxide-dependent and-independent pathways involving JNK and the Bcl-2 family. Cell Cycle 6: 1772-1778.

43. Wang Y, Xie J, Wang N, Li Y, Sun X, Zhang Y, et al. 2013. Lactobacillus casei Zhang modulate cytokine and toll-like receptor expression and beneficially regulate poly I: C-induced immune responses in RAW264.7 macrophages. Microbiol. Immunol. 57: 54-62. 